\title{
Pulmonary choristoma associated with calf meningocele
}

\author{
Coristoma pulmonar e meningocele em um bezerro
}

\author{
Diego Medeiros de Oliveira' João Marcos Araújo Medeiros ${ }^{\mathrm{I}}$ Ana Lucélia de Araújo \\ Luciano da Anunciação Pimentel ${ }^{\mathrm{I}}$ Felipe Pierezan ${ }^{\mathrm{II}}$ Eldinê Gomes Miranda Neto ${ }^{\mathrm{I}}$ \\ Antônio Flávio Medeiros Dantas ${ }^{\mathrm{I}}$ Franklin Riet-Correa $^{\mathrm{I}^{*}}$
}

\begin{abstract}
Pulmonary choristoma is a rare malformation reported in different animal species defined as a mass of normal histological pulmonary tissue in an abnormal location. A case of pulmonary choristoma and meningocele is reported in a calf that presented a fluctuating subcutaneous fluid containing mass, measuring $15 \times 15 \times 20 \mathrm{~cm}$ in the skull frontal region. The skin covering the sac was surgically removed. Macroscopically, subcutaneous nodules up to $2 \mathrm{~cm}$ in diameter with irregular whitish areas mixed with red areas were observed. In the histological examination, pulmonary lobules tissue composed by alveoli, bronchi, bronchioles and cartilage were observed. Dilated blood vessels and hemorrhages were present between the lobules. In this case the pulmonary choristoma was associated with meningocele, and probably was the mechanical cause for the failure of the skull closure.
\end{abstract}

- NOTE -
Key words: calf, pulmonary choristoma, meningocele.

RESUMO

Coristoma pulmonar é uma malformação rara, reportada em diferentes espécies animais. Este trabalho descreve um caso de coristoma pulmonar associado à meningocele em uma bezerra. O animal apresentava uma massa flutuante contendo transudato e medindo $15 \times 15 \times$ $20 \mathrm{~cm}$ na região frontal do crânio. A pele que formava o saco cheio de líquido foi removida cirurgicamente. Por baixo da pele observavam-se nódulos subcutâneos de até $2 \mathrm{~cm}$, irregulares e com áreas esbranquiçadas entremeadas com áreas vermelhas. Na microscopia, observaram-se lóbulos de tecido pulmonar compostos por alvéolos, bronquíolos, brônquios e cartilagem.
Nesse caso, o coristoma pulmonar estava associado à meningocele, e provavelmente foi a causa mecânica do não fechamento do crânio.

Palavras-chave: bovino, coristoma pulmonar, meningocele.

Congenital defects occur in all animal species worldwide. Clinically they are of easy recognition, but it's difficult to determine their etiology. In Brazil, the prevalence of malformations in calves is estimated in $0.5-3 \%$ (SCHILD, 2007). Cranial meningocele is an anomaly of the nervous system, which consists in a protrusion of meninges through a defect in the skull forming a cerebrospinal fluid-filled sac covered by skin (MAXIE \& YOUSSEF, 2007; SUMMERS et al., 1995).

The prevalence of bronchopulmonary malformations is unknown, but they are rare in domestic animals (CHAUVET et al., 1994; CANPOLAT \& ERÖKSÜZ, 2007). Pulmonary choristoma, defined as an aggregation of histologically normal pulmonary tissue in an abnormal location has been reported in different animal species. They can be found in different locations including abdominal or thoracic cavities and subcutaneous tissue (MAXIE \& YOUSSEF, 2007; CHAUVET etal., 1994; CANPOLAT \& ERÖKSÜZ, 2007; LÓPEZ, 2007). Other terms including pulmonary

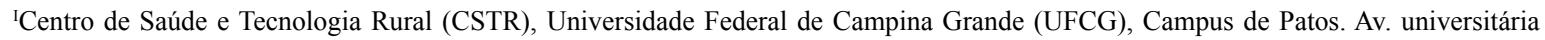
s/n, Santa Cecília, 58700-000, Patos, PB, Brasil. E-mail: franklin.riet@pq.cnpq.br. *Autor para correspondência.

"Laboratório de Patologia Veterinária, Departamento de Patologia, Universidade Federal de Santa Maria (UFSM), Santa Maria, RS, Brasil. 
sequestration, ectopic or accessory lung, and bronchopulmonary foregut malformation have been used to name this malformation (CANPOLAT \& ERÖKSÜZ, 2007).

In February 2008, a 7 days old, female, mixed breed calf weighing $25 \mathrm{~kg}$, from the Municipality of Santa Terezinha, Pernambuco State, northeastern Brazil was sent to the Veterinary Hospital at the University of Campina Grande. The animal had a fluid-filled, subcutaneous mass measuring $15 \times 15 \times 20 \mathrm{~cm}$ in the skull frontal region (Figure 1). The fluid was aspirated and it was similar to cerebrospinal fluid (transparent, odorless, with density of $1.014,1200 \mathrm{mg} \mathrm{dl}^{-1}$ of total protein, and $\mathrm{pH}$ of 8.0 and 1.050 leucocytes $\mathrm{mL}^{-1}$ ). A cranial ventrodorsal radiographic exam showed decreased bone opacity in the skull due to a defect on the fissure in the frontal bone. On the lateral view the frontal bone was protruded and a radiopaque image was observed above the skull. Part of the skin covering the mass was surgically removed. During surgery three liters of serosanguineous fluid were obtained from the mass and a fissure in the frontal bone was observed. The meninges prolapsed thought the fissure, forming a sac covered by meninges and skin. The parietal bone was apparently intact. The excess of skin was removed with a portion of meninges, and both structures were sutured separately. After the surgery the calf was treated with five daily doses of $4 \mathrm{mg} \mathrm{kg}^{-1}$ gentamicine, $40,000 \mathrm{IU}$ $\mathrm{kg}^{-1}$ of penicillin, $2.2 \mathrm{mg} \mathrm{kg}^{-1}$ of flunixin meglumine, and 3 doses of $0.1 \mathrm{mg} \mathrm{kg}^{-1}$ of dexamethasone. Samples of skin were fixed in $10 \%$ buffered formalin and embedded in paraffin wax for histologic examination. Sections of 4-6 $4 \mathrm{~m}$ were stained with hematoxylin and eosin. The calf returned to the farm and the farmer reported that it died five days after surgery. Necropsy was not performed.

Macroscopic examination revealed subcutaneous nodules up to $2 \mathrm{~cm}$ in diameter with irregular whitish areas mixed with red areas. In the histological examination the nodules were composed by lobules with normal pulmonary tissue separated by numerous dilated blood vessels with hemorrhage and edema. Alveoli, bronchi and bronchioles were observed within the lobules (Figure 2). The alveoli were atelectasis and lined by a flattened epithelium. Bronchi and bronchioles were lined by a cylindrical, ciliated, pseudostratified epithelium with caliciform cells. A thin layer of smooth muscle surrounded by connective tissue was observed under the lamina propria of the bronchial epithelium. Cartilage and mucous glands were also observed in the submucosa (Figure 2).

The diagnosis of choristoma was based on the histologic findings. Pulmonary choristomas occur during embryogenesis. They are considered a foregut malformation composed of lung tissue that arises caudal to normal lung and migrates caudally along the growing esophagus (CANPOLAT \& ERÖKSÜZ, 2007). Meningoceles occur as a primary defect of the neural tube in the embryonic ectoderm causing a hernial protrusion of meninges through a defect in the skull or vertebral column (MAXIE \& YOUSSEF, 2007). At least 31 cases of pulmonary choristoma have been reported

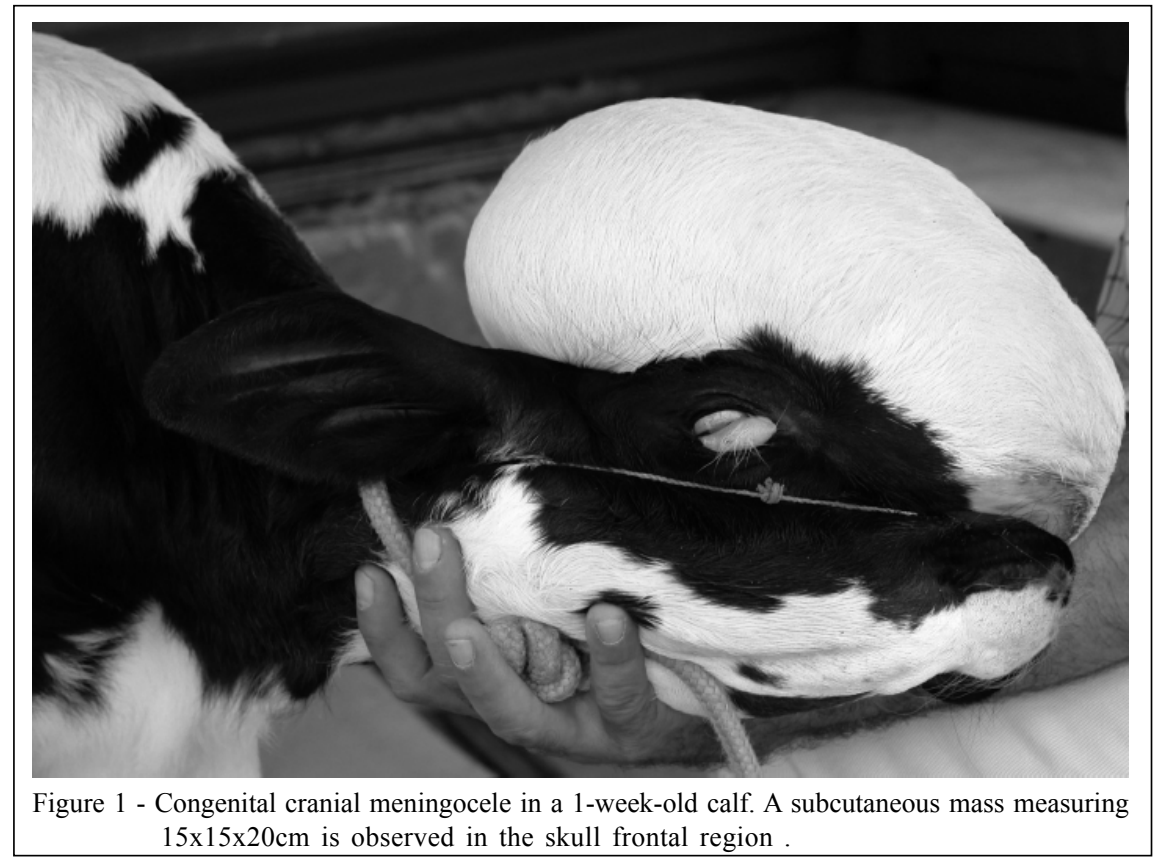

Ciência Rural, v.39, n.9, dez, 2009. 


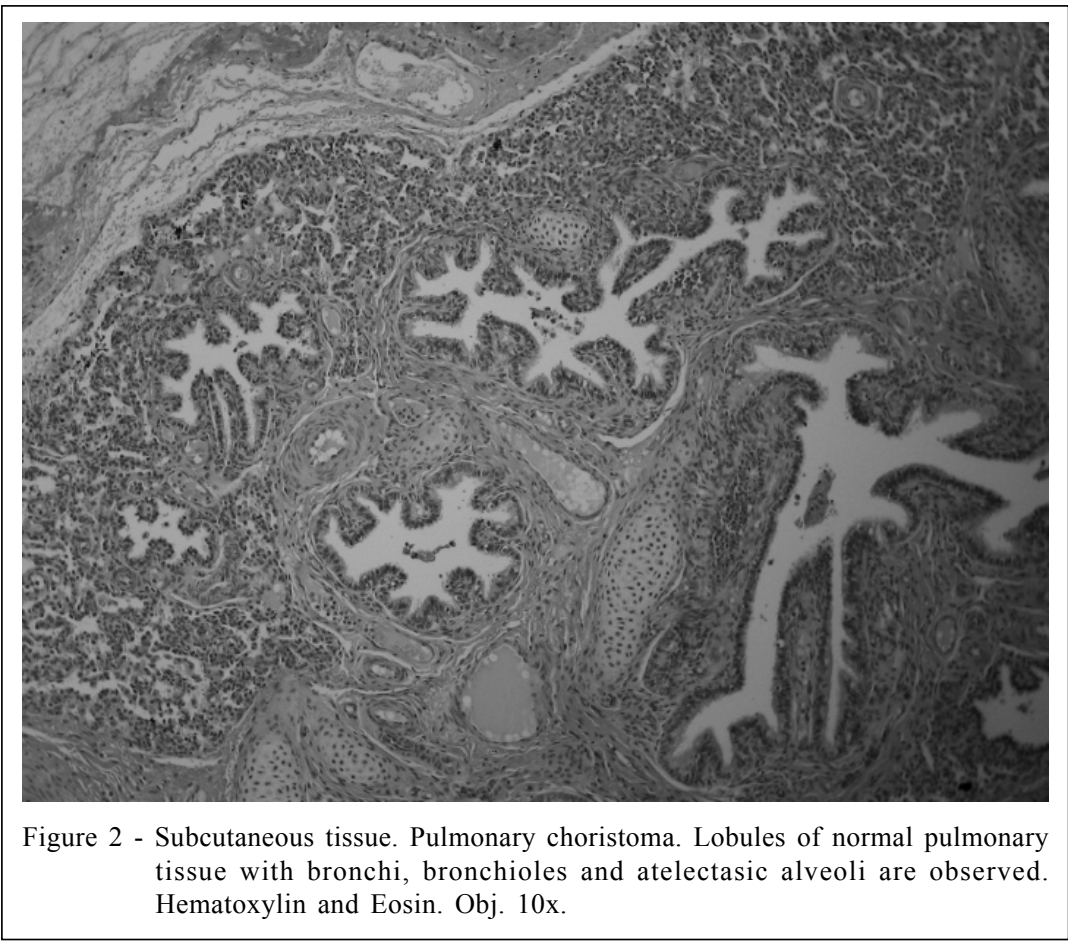

in the literature, $16(52.5 \%)$ in the abdominal cavity, 12 $(38.7 \%)$ in the subcutaneous tissue, and $3(9.7 \%)$ in the thoracic cavity. Those on the subcutaneous tissues were located on neck, sacrum, shoulder (3 cases), thoracic inlet, head, left side of sternum, lumbar (2 cases), and anus (1 case); in another case the location was not informed (CANPOLAT \& ERÖKSÜZ, 2007). In the case herein reported the pulmonary choristoma was associated with meningocele, and probably was a mechanical cause for the failure of the skull closure followed by meningeal exposure. CHAUVET et al. (1994) reported a pulmonary subcutaneous choristoma arising between the occipital protuberance and the spinous process of the second cervical vertebra, but the lesion did not communicate with the subarachnoid space. In this case the animal had no nervous signs. Both pulmonary choristoma (CANPOLAT \& ERÖKSÜZ, 2007) and meningocele (BACK et al., 1991) have a good prognosis after surgery, but in this case the animal died after being transported to the farm.

\section{REFERENCES}

BACK, W. et al. Surgical repair of a cranial meningocele in a calf. Veterinary Record, v.128, n.24, p.569-571, 1991.

CANPOLAT, I.; ERÖKSÜZ, Y. Pulmonary sequestration and bronchogenic cyst in a calf. Firat Üniversitesi Saglik Bilimleri Dergisi, v.21, n.6, p.281-284, 2007.

CHAUVET, A.E. et al. Pulmonary choristoma in a calf. Canadian Veterinary Journal, v.35, n.7, p.441-442, 1994.

LÓPEZ, A. Respiratory system. In: MCGAVIN, M.D.; ZACHARY, J.F. Pathologic basis of veterinary disease. Mosby: St Louis, 2007. Cap.9, p.463-558.

MAXIE, M.G.; YOUSSEF S. Nervous system. In: MAXIE M.G. Jubb, Kennedy, and Palmer's pathology of domestic animals. Oxford: Elsevier, 2007. V.1, cap.3, p.281-456.

SCHILD, A.L. Defeitos congênitos. In: RIET-CORREA, F. et al. Doenças de ruminantes e eqüídeos. Santa Maria: Palloti, 2007. V.1, cap.1, p.25-55.

SUMMERS, B.A. et al. Veterinary neuropathology. Baltimore: Mosby, 1995. 527p. 